\title{
Extracurricular activities and emotional development of students at Lubuk Pakam 2 High School
}

\author{
Tiurmauli \\ \{tiurmaulipakam@gmail.com \} \\ Postgraduate Program, Pelita Kebenaran School of Theology
}

\begin{abstract}
This study aims to determine the impact of extracurricular activities on the emotional development of students at LubukPakam 2 High School. This study uses a quantitative approach with ex post facto method. The population was 300 students of LubukPakam Public High School 2 who participated in extracurricular activities. The sample in this study was $20 \%$ of the total population of 60 people based on proportional random sampling technique. Test Data analysis uses simple regression analysis techniques.The result was that the normality values indicate normal for both extracurricular activities and student emotional development. The analysis uses the test $(\alpha=0.05)$. The results showed a t value of 2.202 with a significant value of 0.032 . Based on the results, it can be concluded that extracurricular activities have an influence on emotional development.
\end{abstract}

Keywords: extracurricular activities, emotional development, students

\section{Introduction}

Extracurricular activities are additional activities outside of school hours both conducted outside and inside the school. The aim is to enrich and broaden the knowledge and abilities of students in various fields of study. Also it is purposed as a means to channeling the talents and interests of students as well as developing students as much as possible. The existence of extracurricular activities in schoolsis expected to be able to support the running of the learning process and also to shape the personality of students to become more mature, making students more willing to express something and be more creative in asking [1-7].

In general, high school students are more influenced by psychological aspects, orin particular, emotional aspects. At the high school age (15-17 years), they will experience emotional characteristics such as: the emergence of adolescent rebellion (expression of changes in childhood into adolescence), the emergence of conflict between children and parents/teachers, and frequent daydreamingthinking about their future [1-3]

By participating in extracurricular activities, students can channel talents, control negative emotions, and reduce emotional stress. By changing the way of thinking, and exercising, students can develop emotions by regulating their emotions. With the ability to hold back emotions, students can achieve their goals and objectives, solve problems, have determination, and can establish good relationships with others. By having high emotional resilience students are able to face certain situations more calmly and can think clearly in finding a way out [1-3].

Extracurricular activities in schools contribute to developing an ability to control their own emotional level the learning process. Students who are active in participating in extracurricular activities have pleasant personalities and are able to socialize well. Extracurricular activities 
programs are designed in such a way that they can support curricular activities and the formation of positive students' personalities [1,2].

The participation of students in extracurricular activities in schools will lead to social interaction in relationships with groups. Social interaction is part of the social factors that can affect the emotional level of students. The existence of social interaction makes it possible to foster changes in new attitudes in students, both positive and negative. If connected with student activities in extracurricular activities, it is seen that students who are active in extracurricular activities will have a better emotional control than students who are not active in extracurricular activities. The reason is because these students have certain advantages, for example the ability of social interaction with teachers or with his friends or with other people around him. Students who are active in extracurricular activities are more disciplined than students who are not active in extracurricular activities [1-3].

LubukPakamPublic High School 2is an educational institution that has extracurricular activities which can be said to have a high level of activity. The extracurricular activities referred to by the researchers at LubukPakam High School 2consist of: sports (futsal, volleyball, badminton, football, basketball, and karate), arts (dance, drama and choir), discipline and society (scouts, flag ceremony team, drug task force, green generation, etc.), and English club. Among adolescence, positive activities are needed in order for them to develop emotions and to prevent them from becoming entangled in negative relationships.

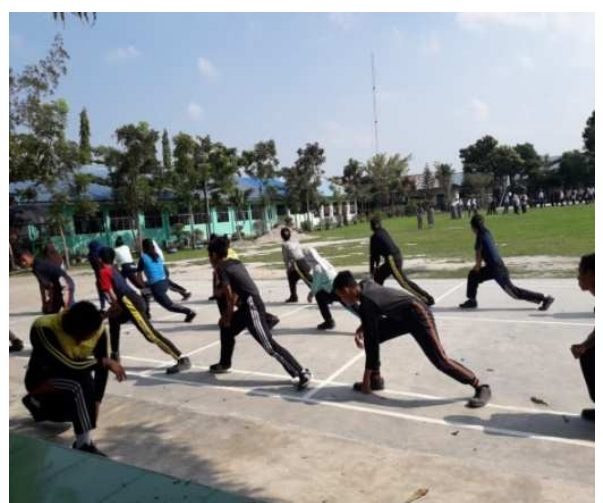

Students doing warm up before exercising

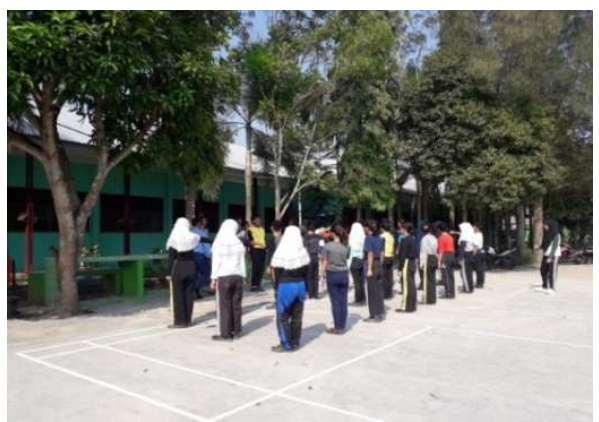

Students following flag ceremony team practice

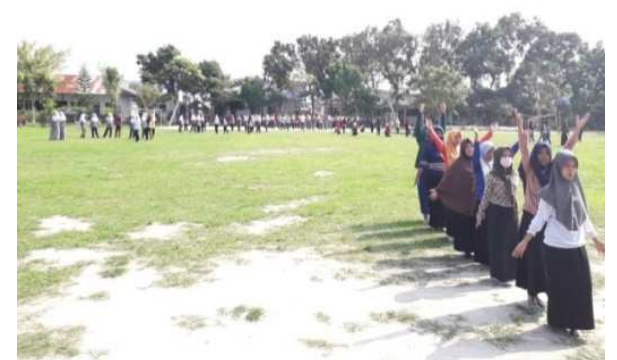

Students following art practice, basketball, and

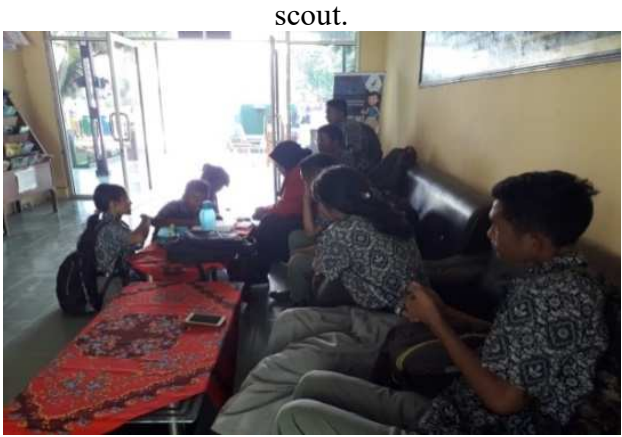

English club 


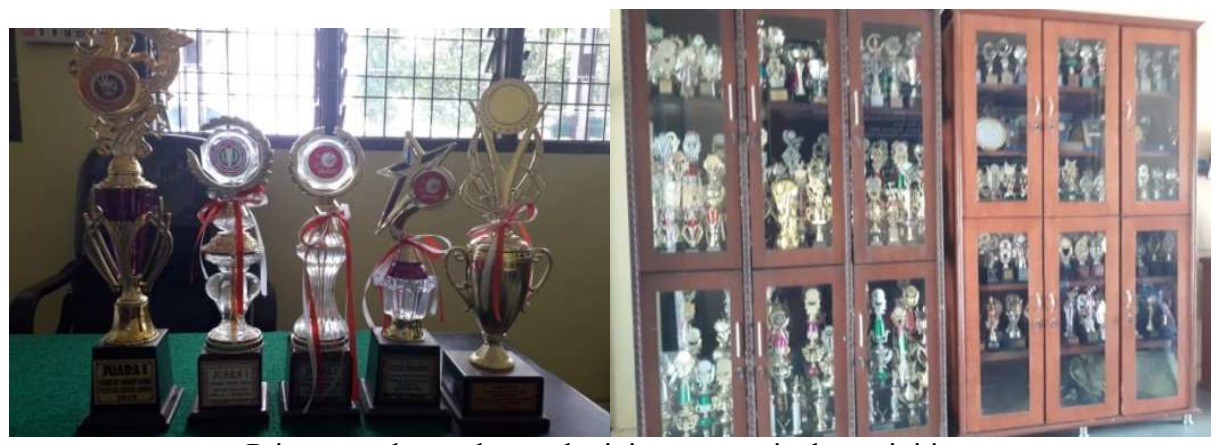

Prizes won by students who join extracurricular activities.

\section{Research methods}

This research is a quantitative study with an ex post facto method, which is a study where treatment of independent variable $(\mathrm{X})$ is not necessary because it has occurred, requiring only to see the effect on the dependent variable (Y). This studyisa quantitative research as the analysis is carried out on numbers using statistical techniques. Quantitative research is research from theory to data, eventually determining acceptance or rejection of the theory used. The population was 300 students from LubukPakam Public High School 2. The sample in this study used a proportional random sampling technique that is $20 \%$ of the total population, hence 60 respondents. The data collection technique wasusing a questionnaire complying to theLikert scale. Test data analysis used simple regression analysis techniques [8,9].The results of the data obtained are then tested for hypotheses and assumption tests. Assumption test consists of normality test and partial test ( $\mathrm{t}$ test).

\section{Results and Discussion}

\subsection{Normality test}

The normality test is used to determine whether the population of the data is normally distributed or not. Normality testing in this study is used to test the variable extracurricular activities (X), and student emotional development (Y). Normality test is a test to determine the normal distribution of data. The data that has been distributed must be analyzed to determine whether the assumption of normality is fulfilled or not, so that the data can be further processed in the diagram and can be used for subsequent data processing.

Table 1. Results of the normality test analysis of variable extracurricular activities (X) on the emotional development of students (Y) in LubukPakam High School2

\begin{tabular}{|c|c|c|c|}
\hline \multicolumn{4}{|c|}{ One-Sample Kolmogorov-Smirnov Test } \\
\hline & & $\mathrm{X}$ & $\mathrm{Y}$ \\
\hline $\mathrm{N}$ & & 60 & 60 \\
\hline Normal Parameters ${ }^{\mathrm{a}, \mathrm{b}}$ & Mean & 88,47 & 82,03 \\
\hline
\end{tabular}




\begin{tabular}{llrr}
\hline \multicolumn{4}{c}{ One-Sample Kolmogorov-Smirnov Test } \\
& & X & \multicolumn{1}{c}{ Y } \\
\hline \multirow{2}{*}{ Most Extreme Differences } & Std. Deviation & 2,902 & 3,324 \\
& Absolute &, 123 &, 146 \\
& Positive &, 077 &, 119 \\
& Negative &,- 123 &,- 146 \\
Kolmogorov-Smirnov Z & &, 952 & 1,131 \\
Asymp. Sig. (2-tailed) & &, 325 &, 155 \\
\hline & Source :research data (2019) & &
\end{tabular}

The results of the research obtained through the SPSS version 20.0 program indicate that the absolute value of the extracurricular activity variable $(\mathrm{X})$ is 0.123 then $0.123<0.172$ which means the data is normally distributed. This is also proven by the results of the probability test on SPSS which can be seen in the value of Asymp. Sig. (2-tailed) the value is 0.325 where $0.325>0.05$ means that the data is normally distributed.

From the table above it can be seen that the absolute value of the variable student emotional development $(\mathrm{Y})$ is 0.146 then $0.146<0.172$ which means the data are normally distributed. This can be proven by the results of the probability test on SPSS, namely the Asymp.Sig. (2tailed) the value is 0.155 where $0.155>0.05$ means that the data is normally distributed.

\subsection{Partial Test (t Test)}

The $\mathrm{T}$ test is used to determine the significance of the influence of each independent variable (extracurricular activities) on the emotional development of the students, to determine whether or not the hypothesis is acceptable.

Table 2. Results of simple linear regression analysis of extracurricular activities variable (X) on the emotional development of LubukPakam High School 2students

\begin{tabular}{|c|c|c|c|c|}
\hline \multirow{3}{*}{ Model } & \multicolumn{2}{|c|}{ Coefficients $^{\mathbf{a}}$} & \multirow{3}{*}{$\mathrm{t}$} & \multirow{3}{*}{ Sig. } \\
\hline & Unstandardized Coefficients & \multirow{2}{*}{$\begin{array}{c}\text { Standardized } \\
\text { Coefficients } \\
\text { Beta }\end{array}$} & & \\
\hline & Std. Error & & & \\
\hline (Constant) & 12,789 & & 4,214 & .000 \\
\hline X &, 318 & ,278 & 2,202 & 032 \\
\hline
\end{tabular}

The table above shows that the extracurricular activity variable has a value of $t$ count $2.202>\mathrm{t}$ table 2.00 with a significant level of $0.032<0.05$. Therefore the Ho is rejected and Ha accepted. Based on this, there is evidence of a significant influence between extracurricular activities on the emotional development of students in LubukPakam High School2.

From the research data obtained, it can be concluded that the implementation of extracurricular activities that are good in the school environment of LubukPakamPublic High School 2 can influence the emotional development of students even though the magnitude of the influence varies. The better the implementation of extracurricular activities, the higher the level of emotional development of students will become.

Extracurricular activities are a component of self-development that must be facilitated by the school in order to provide opportunities for students to develop and express themselves according to the needs and interests of each student. Students who display a high emotional state 
will be better in controlling the emotions that are felt; students are able to express feelings appropriately, sympathetic, sociable, able to recognize the emotions of others and respond positively. Extracurricular activities are one of the very positive activities carried out in schools where these activities can help students to develop their emotions and can solve problems faced.

\section{Conclusion}

Based on the research that has been carried out, it can be concluded that there is an influence of extracurricular activities on the emotional development of students in LubukPakam High School 2. The higher the implementation of extracurricular activities followed by students, the higher the level of emotional development so that students are able to master their emotions.

\section{Acknowledgements}

Acknowledgments and appreciation is directed to the PelitaKebenaran School of Theology, Medan and LubukPakam High School 2 for helping in completing this research. In addition, the authors would also like to thank the parties who helped in the process of preparing research reports that could not be mentioned one by one.

\section{Reference}

[1] Wiratmoko, A 2012 pengaruh Kegiatan Ekstrakurikuler Robotika Terhadap Kecerdasan Emosional Siswa Di SMK Negeri 3 Yogyakarta

[2] Setyawan, I dan Profitra Reza Akbar 2015 Perbedaan Kecerdasan Emosional Antara Siswa SMA Dengan MA : Studi Komparasi Pada Siswa Kelas XI Di SMA N 1 Purwodadi Dan MA Sunniyyah Selo Jurnal Empati Volume 4(4), 202-207

[3] Takdir 2017 Pengaruh Kegiatan Ekstrakurikuler Terhadap Peningkatan Kemampuan Konsep Diri (Self Consept) Peserta Didik SMA Negeri 1 Sinjai Timur Kabupaten Sinjai

[4] Fahrudin, M 2014 Pengaruh Keaktifan Siswa Dalam Kegiatan Ektrakurikuler Di Sekolah Dan Motivasi Belajar Terhadap Prestasi Belajar Akuntansi Siswa Kelas X Akuntansi SMK Negeri 2 Purworejo Tahun Ajaran 2013/2014

[5] Sudarma, K dan Hengky Pramusinto Pengaruh Kegiatan Ekstrakurikuler dan Perilaku Belajar Terhadap Prestasi Akademik Pada Mata Pelajaran Ekonomi Kelas XI IS di SMA Negeri 7 Semarang

[6] Ivaniushina, V,A and Oksana O. Zapletina 2015 Participation in Extracurricular Activities and Development of Personal and Interpersonal Skills in Adolescents Journal of Siberian Federal University. Humanities \& Social Sciences 11 (2015 8) 2408-242 
[7] Dewi N. K. dan Sahat Saragih 2014 Pengaruh Kegiatan Ekstrakurikuler Kepramukaan Terhadap Perilaku Prososial Remaja Di SMP Santa Ursula Jakarta Persona, Jurnal Psikologi Indonesia September 2014, Vol. 3, No. 03, hal 253 - 268

[8] Arikunto, Suharsimi. 2010. Prosedur Penelitian Suatu Pendekatan Praktik. Jakarta: Rineka Cipta.

[9] Sugiyono dan Agus Susanto 2015 Cara Mudah Belajar SPSS \& Lisrel Alfabeta Bandung 